\title{
On Allomyces, a new Aquatic Fungus.
}

\author{
BY \\ E. J. BUTLER, M.B., F.L.S. \\ Imperial Mycologist, Agricultural Research Institute, Pusa, India.
}

With Figures I-I8.

MONG the aquatic Phycomycetes few are more interesting than the Oomycetes characterized by the filaments being segmented through the presence of successive constrictions, with oogonia, when present, containing a single oosphere surrounded by periplasm. The family was included by Schroeter with the Saprolegniaceae and Pythiaceae in the order Saprolegniineae, but Thaxter ('06, p. 324) subsequently pointed out that its affinities with the Pythiaceae must cause it to be transferred to the Peronosporaceae if Pythium be united to the latter family.

It is probable, however, that the Leptomitaceae are more primitive forms than either the Saprolegniaceae or Pythium, and I have suggested ('07, p. $\left.5^{8}\right)$ that they may show indications of affinity with the curious genus Monoblepharis and through it with the green Algae (Siphoneae or Oedogoniaceae). The number of forms known to belong to the family is small, and it is therefore of decided interest to encounter a new one with distinctive characters.

The Fungus occurs in Pusa in still (but not stagnant) water, and in Poona in river water, in both cases growing on dead flies, \&c., which have fallen in. The plants may be single or two or more may occur together, the growth presenting to the naked eye the familiar appearance of a Saprolegnia colony. It can be readily isolated from accompanying Phycomycetes by suspending dead sterile flies or ants near the surface of a dish full of water in which a few sporangia ready to discharge are placed. It grows freely in such cultures, and is not much hindered by the development of Bacteria as in some of the allied forms.

The plant consists of a distinct basal part formed of several very large cells, sometimes arranged in a single column, sometimes in a dichotomously branched system. From the distal end of this, whorls of more slender

[Annals of Botany, Vol. XXV. No. C. October, 1911.] 
fertile branches arise, which bear the reproductive organs, sporangia and resting spores. From the basal cell numerous fine branched rhizoids penetrate the substratum. The most striking character of the plant, in view of its being an undoubted Phycomycete, is that it is distinctly multicellular, all parts, except the rhizoids, being regularly septate.

The various parts may now be described in detail.

The basal portion is anchored to the substratum by a branching system of rhizoids arising from the lowermost cell. The lowest cell itself is variable in shape, sometimes almost square, sometimes oblong or clavate (Figs. I-3). It measures from 100 to $200 \mu$ in length by $60-100 \mu$ in breadth, and is thick-walled, but not rigid. Above, it is either continued into a short column of three or four similar cells (Fig. 3), or branches dichotomously to form a fan-shaped body of large cells (Fig. 2). These again branch upwards, the succeeding branches being more slender and the tendency to dichotomy being usually lost. Frequently, whorls of three branches arise from the uppermost of the basal cells, but there is no regularity about this; dichotomy may be preserved for some time or the branches may arise at different levels from near the end of the basal cells. Each branch is cut off by a septum at the point of origin, and after the mass of basal cells is left, any branch may terminate in a sporangium, growth being usually renewed just below the sporangium, and the latter being then pushed a little to one side.

The fertile branches radiate from the basal cells and are composed of septate hyphae, the cells reaching an extreme length of $25 \circ \mu$, with a breadth of $15^{-2} 5 \mu$. Usually a terminal sporangium is formed before growth has proceeded very far, and the axis is continued by a branch arising just below the sporangium, somewhat as in Phytophthora vexans. This may be repeated many times, each fertile axis thus forming a sympodium, as in Fig. 5; or branching of a more or less dichotomous type may occur, as in Fig. 4. In this case, as probably in all other cases of the sort amongst the Fungi, one of the branches arises a little behind the apex of the filament, apparent equality of origin being only subsequently reached. Ultimately the apex of every branch ends in a sporangium or chain of sporangia or a resting spore. The walls of the fertile branches are thin. The septa are formed regularly behind the growing apex, but secondary septation may occur at a later stage. Usually one develops at or near the origin of each branch. Sometimes they occur at more or less regular intervals throughout the axis, sometimes several are formed close together below a sporangium (Fig. I). They appear to be laid down in interrupted plates from the periphery of the tube (Fig. I7, $c$ ). Usually they are complete, but rarely a small pore appears to be left in the centre, as in some, at least, of the higher Fungi. In no case observed was the septum reduced to a mere annular thickening, such as occurs in Gonapodya. The segments 
are usually slightly constricted at the septum, except at the origin of a branch.

The sporangia are formed in great abundance, either singly or in basipetal chains, at the ends of the hyphae. They are ovoid or barrel-shaped cells measuring $40-70$ by $30-40 \mu$, with thin walls and granular hyaline contents. They are always inserted by a broad base on the ends of the fertile hyphae, from which they are cut off by a well-developed septum. Rarely, after a sporangium has formed at the end of a hypha and the axis has continued to grow from below it, a segment immediately beneath the origin of the branch becomes transformed into a sporangium. Fig. 1, $a$, shows such a case, the lowest sporangium having been formed after the upper was cut off and a new branch had arisen below it. Similarly, two sporangia may appear to arise side by side from the lowest of a chain so as to result in the production of a branched chain. In this case also the lowest is the last formed. By a repetition of subsporangial branching with early formation of new sporangia, rather complicated clusters of these organs may be formed, Fig. 6 showing one of the types met with. The contents of the mature sporangium are hyaline and granular. The papillae of discharge appear quite soon and are usually several in each sporangium. Fig. 7 shows a chain of ripe sporangia with the papillae formed and ready to burst. Usually there are two to four, less often only a single terminal one. They are large, very brightly refractive, and evidently formed of a protusion of the softened sporangial wall. They generally rupture simultaneously, or almost so, to emit the zoospores.

The zoospores are formed before the rupture of the papillae, being visible as rounded masses tightly filling the sporangium. The papillae then dissolve without any trace of the formation of a vesicle such as occurs in other Leptomitaceae (Rhipidium, Araiospora, Sapromyces). At first the zoospores pass out rapidly, though singly, separating immediately on exit. Later, as the crowd within becomes less dense, they emerge slowly, often with a more or less creeping movement. The last few left within the sporangium wander slowly, and with frequent amoeboid movements, around the walls and cavity, ultimately becoming engaged in one of the openings and creeping out. After exit, the zoospore lies near the sporangium for some time, up to five or ten minutes, and goes through a series of remarkable amoeboid changes. As it emerges it has usually the shape shown in the upper part of Fig. IO, a hyaline cap occupying the anterior end of the elongated body, and a single long and moderately stout cilium the posterior. The subsequent changes in shape are shown on the left-hand side in Fig. Io, drawn from a single spore. During these changes it is sometimes difficult to see the cilium, but it appears to be persistent. At the end of the amoeboid period the zoospore takes on the shape shown at the bottom of Fig. IO, and swims rapidly away. The swarming period 
may last up to about half an hour, when the spores come to rest, still waving slowly their cilium, round off, the cilium disappears, and the spore surrounds itself with a wall. Germination is visible often within an hour of discharge, the germ-tube being single, slender, and branched. The zoospores are monoplanetic. I have made a most careful search for biciliate zoospores, the cilia being well fixed, and stained with iodine, and easy to see, and there is not the slightest doubt that in my cultures the spores were uniciliate. The point is necessary of emphasis on account of the importance sometimes attributed to this character, and also because of the observations made on Blastocladia, which appears to be a nearly allied genus. The latter has usually biciliate zoospores, but in some cases Thaxter, who has most closely studied it, failed to make out more than one cilium. Reinsch, who first observed it, did not describe the characters of the zoospores. The only other observer who appears to have encountered it is Petersen, who states that the zoospores are amoeboid and uniciliate. The remarkable triangular nucleus described by Thaxter in the zoospores of Blastocladia was not observed in the Indian Fungus.

Besides sporangia a second type of reproductive body occurs which is of much interest. This is a sort of resting spore of distinctive shape and structure. It is formed invariably at the end of peripheral branches of the fertile hyphae, and appears later than the sporangia, though mature cultures bear both organs. The early stages of its formation are just as in the sporangium, the end of the hypha swelling up into a club-shaped body which is cut off by a septum. Within this the resting spore develops as a thick-walled, brown cell, truncate pear-shaped and with a sculptured wall. Frequently this cell fills the swollen end of the hypha so completely that the investing wall is merged in the exospore of the resting spore. In other cases a space is visible between them which is generally most distinct on the side of the septum, but is also often seen right round the spore. The resting spore is thus formed free within the terminal cell of the hypha, a character which removes it far from the category of conidia such as those of the Peronosporaceae. It is set free by the rupture of the enclosing membrane at a late stage in the life of the plant (Fig. I5) or, in those cases in which the membrane is closely applied to the exospore of the resting spore, by the abjunction of the whole upper segment of the hypha. The resting spore is yellowish brown when young, becoming a rich deep brown when mature. Its wall is composed of two layers, an outer, thick, brown and with distinct markings and an inner, thin, structureless and probably hyaline, though the latter character would only be determinable in an actual section which was not obtained. The structure of the exospore is exactly similar to that described by Thaxter for the resting spore of Blastocladia, and, as his description is full, need not be further referred to. In those cases where the wall of the containing cell of the spore is closely 
applied to the exospore and thrown off with the spore, it is visible on careful focusing as a thin hyaline third wall external to the others (Fig I3).

The diagnosis of this Fungus, for which I propose the name Allomyces arbuscula, n.g., n.sp., is as follows:-

Allomyces, n.g. Plant consisting of a large-celled basal body or foot, branched above, from which arise the slender fertile filaments; filaments septate, branched sympodially or dichotomously, branches terminating in sporangia or resting spores; sporangia single or catenulate, ovoid, with several papillae of discharge; zoospores emerging singly, without formation of a vesicle, large, oblong or elliptical, I-ciliate, amoeboid at first, monoplanetic; resting spores terminal, ovoid, thick-walled, formed within the terminal cell of the filament and set free by its rupture, or sometimes completely filling it and then thrown off with the terminal cell, germination not seen; membranes of all parts without cellulose.

Allomyces arbuscula, Butl. Basal body of large cells 100-200 by $60-100 \mu$, attached below by rhizoids to the substratum, and one or more times dichotomously branched above; fertile filaments arising in groups of two or more from the end segments of the basal body, septate, cells up to 250 by $\mathrm{I} 5^{-25} \mu$, sympodially or less often dichotomously branched, each branch terminated by a sporangium or chain of sporangia or a resting spore; sporangia broad elliptical, or ovoid, $40-70$ by $30-40 \mu$, ends bluntly rounded or truncate, with one to four papillae of discharge; resting spores single, terminal, truncate below, rounded above, with thick brown pitted exospore, $40-60$ by $30-45 \mu$.

The affinities of this Fungus must now be considered. The differentiation of the thallus into a dilated basal part and more slender fertile branches is a feature common to several genera of the Leptomitaceae (Rhipidium, Araiospora, Sapromyces) and also Blastocladia, the position of which is doubtful. This basal cell of certain Leptomitaceae is a structure which has appealed to all who have studied the group as of great taxonomic importance. Nothing like it is known in the other Phycomycetes. Usually it is a single cell which may be variously branched or lobed. In Rhipidium americanum the branching is more or less dichotomous, and if septation were to occur the result would resemble in all essential respects the basal body of the new Fungus. The same holds good for Blastocladia to an even greater degree. Hence, in spite of the multicellular structure of the basal body of Allomyces, it must be held to represent the basal cell of these genera.

The segmentation of the mycelium is a distinguishing feature of the Leptomitaceae, including Gonapodya, but not Blastocladia. It is unknown in other Phycomycetes except the Ancylistaceae, where every segment 
becomes a reproductive organ. The nearest approach to it is found in the Saprolegniaceae, in several of which the old mycelium may segment to form 'gemmae' and in one case, Saprolegnia torulosa, de Bary, segmentation is normal. This segmentation is, however, of quite another order to that of the Leptomitaceae (cf. Maurizio, '96). In the latter group the segmentation is not a phenomenon of budding and only rarely is the interruption between successive filaments complete; usually a central passage, through which the protoplasm of adjacent segments is in direct communication, is left. In Rhipidium continuum and some plants of Gonapodya polymorpha the segmentation is obscure or lost. In Apodya lactea, however, the passage may be entirely closed by a deposit of cellulin; the process has been fully described by Pringsheim ('85). In Gonapodya something similar occurs, according to Thaxter, while Petersen's figures ('10, pp. 533-4) show complete interruption. In the cases examined by Pringsheim the passage is blocked by one or more cellulin corpuscles which move into it from the adjacent segments and become fused with the walls. In the new Fungus the process is different, a distinct membrane being thrown across the cell by an ingrowth or deposit which begins at the periphery and gradually extends to the centre (Fig. I7,c). Nevertheless, in its formation it is probable that the cellulin granules take part. These bodies are numerous and distinct and become massed at the point where the septum is developing (Fig. $17, a, b$ ). They are ultimately divided into an upper and a lower group by the formation of the septum. The resemblance to what occurs in the differentiation of the sporangium in Saprolegnia, as described by Rothert ('90), is considerable, though in the latter case the whole septum appears simultaneously and not by an ingrowth from the periphery. It is clear that the case represents a more advanced stage in the segmentation of the Leptomitaceae and is not comparable to the true septation of the higher Fungi. The resulting septum is usually thin and similar to the cell-walls, but it is sometimes thick and irregular, as in Apodya (Fig. I7,e).

The sympodial axes of the fertile hyphae, the basipetal development of the sporangia, and the position of the reproductive organs are minor, but interesting points of affinity between the Fungus above described and the Leptomitaceae. Rhipidium and Apodachlya should be compared on these points.

The peculiar resting spore is more important and its homology with that of Blastocladia evident. Apodachlya, an undoubted member of the Leptomitaceae, is the only other Oomycete with thick-walled resting spores which can at all be compared with these. The conidia of Pythium and the higher Phycomycetes are merely modified sporangia, and hence belong to another spore category.

In view of the above characters, the inclusion of the new Fungus amongst 
the Leptomitaceae is inevitable if we are to unite it to any of the recognized families of the Phycomycetes.

There are, however, two characters of considerable weight which the new Fungus possesses in common with Gonapodya and less definitely with Blastocladia, which separate these three forms widely from the other Leptomitaceae. These are the composition of the cell membrane and the character of the zoospores.

Of the authors who observed the two latter genera, Reinsch and Thaxter do not mention the composition of the membrane. Cornu ('72, p. I5) stated that Monoblepharis (in which he included Reinsch's Saprolegnia siliquaeformis = Gonapodya siliquaeformis, Fischer) is devoid of cellulose. Recently Petersen states that this is the case with both Blastocladia and Gonapodya. The new Fungus gives a reddish yellow colour with chloriodide of zinc, the wall of the resting spores being particularly deeply stained, and can be sharply distinguished by this means from Saprolegniaceae (Saprolegnia and Achlya), with which it is growing, the latter taking a clear blue colour. It is therefore in this respect more closely allied to Blastocladia and Gonapodya than to the other Leptomitaceae. Monoblepharis is the only other Oomycete giving a similar reaction.

As regards the zoospores, the form observed in Pusa was constantly I-ciliate. Gonapodya also has I-ciliate zoospores, according to Cornu and Thaxter, though the latter states that they have sometimes seemed to be 2-ciliate. Reinsch and Petersen do not specifically remark on this point. In Blastocladia there appears to be some doubt. Thaxter describes the zoospores as normally 2 -ciliate, but sometimes only one cilium can be found ; Petersen says that they are I-ciliate. In shape and behaviour all three are allied, those of Gonapodya in particular having, like Allomyces, a short period of amoeboid movement after emerging from the sporangium. In the other Leptomitaceae the normal 2-ciliate zoospore of the Oomycetes is found.

These three forms are therefore similar in that they possess certain important characters differentiating them from the other members of Schroeter's family Leptomitaceae. Whether Gonapodya and Blastocladia were rightly included by Schroeter in this family is uncertain. Thaxter ('96, p. 325) doubtfully includes Gonapodya, but excludes Blastocladia. Petersen makes a separate family for each, Gonapodyaceae and Blastocladiaceae. Allomyces is clearly allied to the latter and serves to unite it more closely with the true Leptomitaceae. On the whole, though the character of the membrane is such as to prevent dogmatism, the new form tends to strengthen Schroeter's view and to indicate real affinity within the limits of the family as defined by him.

In 1907 I suggested that the peculiar Phycomycete Monoblepharis, the only known Fungus with motile sperms, was related more to the Leptomi- 
taceae than to any other family. Is there any hint in the Fungus above described of affinity with this isolated genus? I think so. The resting spore, formed free within a cell of the mycelium, is something new amongst the Oomycetes, so much so that the possibility of there being a fertilization by antherozoids, as in Monoblepharis, requires to be carefully considered. I do not think that anything of the sort can occur. These bodies were formed in great abundance in the cultures, so that fertilization even by small motile sperms was unlikely to have been overlooked. Besides, all the sporangia give rise to zoospores of uniform type, and nothing was seen suggesting antheridia and sperms. In Blastocladia the same idea was present to Thaxter, but he failed to find anything in favour of it. Yet the resting spore of Blastocladia is certainly of the same type as that above described. What then are these bodies, so unlike any asexual spore known in the Oonycetes? I think they are parthenogenetic oospores, derived from a form resembling Monoblepharis.

In Monoblepharis, oospores sometimes develop without fecundation. Lagerheim figures such cases ('00, Figs. 55,56 ), the spore remaining within the oogonium, though the fertilized oospores of the same species ( $M$. brachyandra) emerge after copulation. In other species (e.g. M. insignis, Thaxter) the fertilized oospore remains within the oogonium. A consideration of the published figures of these species will I think show that there is nothing which militates against the homology here suggested. Certainly it is difficult to think of any other spore form in the Phycomycetes with which to compare these bodies. In other respects, Monoblepharis has strong points of resemblance to the three aberrant genera of the Leptomitaceae whose affinities have been referred to above. Like them its zoospore is, at least sometimes, I-ciliate; its very variability in this respect recalls Thaxter's difficulty with the cilia of Blastocladia and Gonapodya; all other Oomycetes have 2-ciliate zoospores. Like them its membrane is devoid of cellulose; all other Oomycetes have cellulose walls. Like Allomyces its sporangia are basipetally formed, and its axis is often markedly sympodial (cf. Lagerheim, '00, Taf. ii, Fig. I6). The peculiar alveolate protoplasm of the vegetative hyphae or Monoblepharis is not marked in Gonapodya or Blastocladia, but is sometimes visible in the new form (Fig. I8). As further strengthening the relationship we have the imperfectly known Fungus, called by Lagerheim Monoblepharis regignens. This has the alveolate protoplasm of the latter genus, but the proliferous siliqua-shaped sporangia of Gonapodya. It has I-ciliate zoospores, other reproductive organs being unknown. Whether this is a true Monoblepharis or not, it is a further connecting link between that genus and Gonapodya. There seems to be no longer any reason for assigning to Monoblepharis an isolated position amongst the Phycomycetes. It is connected, not very distantly, with a group of genera with non-cellulose walls, and these again are con- 
nected by many essential characters, through Allomyces, with the typical Leptomitaceae.

Of this series Monoblepharis must be taken, I think, to preserve the most primitive characters in its peculiar sexual processes. Of recent years algologists have been more ready to admit its affinities with the green Algae than mycologists. Fischer ('92), Schroeter ('99), Dangeard ('06), and Atkinson ('09) in particular derive the whole of the Phycomycetes from the Monadineae, Flagellatae, or Protococcoideae. The most recent and perhaps the most thorough exposition of this view is Atkinson's. He vigorously combats the older idea that the Ancylistaceae and Chytridiaceae have been derived from saprophytic Phycomycetes through the debasing influences of parasitism. This is clearly not capable of direct proof, and there are numerous instances to be drawn from other groups in support of either argument. He attaches great importance to the phenomenon of diplanetism of the zoospores and traces its development from a simplified process in true Chytridiaceae, such as Rhizidiomyces, to its full perfection in the Saprolegniaceae. But a similar origin may be found for it amongst Algae, such as Chlorosphaera, Chlorochytrium, Ulothrix, \&c., and it is in any case doubtful if the simplified process referred to has anything to do with true diplanetism. He does not attach much importance to the number of cilia on the zoospores as a basis of classification, nor does he consider that variability in this character need militate against the monophyletic view. A consideration of the conditions found in the Leptomitaceae in this respect certainly supports him here. Monoblepharis is not in his opinion a primitive Fungus, but may have developed its peculiar sexual processes independently, through change in the function of the zoospores. In the other Phycomycetes the sexual processes of Pythium and the Ancylistaceae are obviously allied to one another, but it is difficult to follow him when he connects these with the Chytridiaceae through Polyphagus and Zygorhizidium. He has possibly overlooked Dangeard's ('00) account of the cytology of Polyphagus, which is monoenergid in the vegetative and gametic stages. Zygorhizidium again appears to be monoenergid, while the sexuality of other Chytridiaceae is doubtful. Finally, after a review of the developmental characters of the two groups, Atkinson concludes that there are more points of similarity between the higher Phycomycetes and the Chytridiaceae than between the former and any of the Algae which have been suggested as their probable ancestors. This is undoubtedly true so long as Monoblepharis remains in the isolated position usually assigned to it by mycologists.

Petersen ('10) also considers that it is possible to unite the Chytridiaceae and Oomycetes in direct relationship, but he inverts the developmental line above suggested, and believes that the Chytridiaceae are degenerate members derived from the level of the Saprolegniineae (including the 
Leptomitaceae) or Monoblepharis. This suggestion was first made by de Bary and has since been adopted by many botanists. Petersen admits that possibly the I-ciliate series is derived from certain Algae, without any intermediate stage of myceliated Phycomycetes. If the latter, then the algal ancestors of the 2-ciliate series must have been closely related to those of the I-ciliate forms. It would take too long to follow him here, but one point deserves special attention. Like Atkinson he does not consider that the I-ciliate and 2-ciliate species need necessarily indicate two distinct groups, but there are nevertheless differences between them of great importance. He makes the general statement that the membrane of all the species with 2-ciliate zoospores contains cellulose, while most of the I-ciliate forms are without this substance, and only a few (endophytic) forms have traces of it. If this is true (and we have seen above that it holds good for the Leptomitaceae) it is probably a generalization of great significance.

Vuillemin ('07) and Lotsy ('07) have been still more impressed by the differences between the I-ciliate and 2-ciliate groups. They refer the latter to the series of the Isocontae of the green Algae. But Vuillemin adopts the Monadine theory of the origin of the I-ciliate series, and Lotsy derives them from many lower organisms, more simple than the Isocontae. To both, Monoblepharis is a stumbling-block. Vuillemin ('07, p. 106) says of this genus: 'C'est un genre exceptionnel par ses organes reproducteurs comme par ses organes sexuels. Il a des allures de genre primitif avec ses spermatozoïdes, uniques parmi les champignons filamenteux. Il n'a pas de parenté plus plausible avec les autres champignons qu'avec les Algues vertes, telles que les $E$ dogonium auxquels Lagerheim le compare, ou avec les Vaucheria qui en seraient les ancêtres d'après Thaxter. Il est donc à souhaiter que ses affinités soient précisées par la découverte de formes nouvelles.'

I think that a consideration of the characters of the Leptomitaceae brought into evidence by the new Fungus above described may help to diminish these difficulties. On the one hand, Monoblepharis is brought into probable relationship with a group of aquatic Phycomycetes in which the zoospore may be I- or 2-ciliate, the thallus segmented or not, and the membrane with or without cellulose. On the other, the members of this group show marked signs of affinity with the green Algae. The form described by Ernst ('02) as Dichotomosiphon, an ally of Vaucheria, is extraordinarily like Allomyces in several respects. From a common stalk fertile branches arise, chiefly dichotomously. These branches are constricted at their origin and segmented at intervals by a ring which does not entirely occlude the passage. The cell-wall gives the ordinary reactions of cellulose, except that it is coloured yellow by chloriodide of zinc. Though this Alga forms starch, its nearest ally Vaucheria does not. The position of 
its sexual organs resembles that found in several Leptomitaceae, but fertilization is effected by 2-ciliate spermatozoids, and so far as is known resembles the process in Vaucheria. The asexual reproduction is so far only known through the formation of 'gemmae', which are held to be sporangia reduced to conidia as occurs in the higher Phycomycetes.

While, therefore, it is not safe to be dogmatic in regard to the origin of the Oomycetes, the discovery of new forms (Dichotomosiphon, Allomyces) strengthens the old view of their derivation from the Siphoneae. Only by further discoveries can this view be proved or disproved. Perhaps also the equally obscure question of the origin of the Chytridiaceae can only be solved in the same manner.

\section{Summary.}

In the above paper a description is given of an Indian aquatic Fungus, Allomyces arbuscula, n.g., n.sp., belonging to the family Leptomitaceae of Schroeter. It is an aberrant member of the family, inasmuch as it has a completely segmented thallus. Its nearest ally is probably Blastocladia, and with this genus and Gonapodya it constitutes a group of forms with non-cellulose walls and predominantly I-ciliate zoospores. This group is believed to show decided indications of affinity to Monoblepharis, the peculiar resting spores of Allomyces and Blastocladia in particular being held to be parthenogenetically developed oospores derived from the Monoblepharis type. The Leptomitaceae are probably a more primitive family than either the Saprolegniaceae or Pythium, and have perhaps been derived through forms resembling Monoblepharis from the Siphoneae amongst the green Algae.

\section{LITERATURE.}

Atrinson, G. F. ('09): Some Problems in the Evolution of the Lower Fungi. Ann. Myc., vii. Butler, E. J. ('07): An Account of the Genus Pythium and some Chytridiaceae. Mem. Dept. of Ag., India, Bot. Ser., i, No. 5 .

Cornu, M. ('72) : Monographie des Saprolégniées. Ann. Sc. Nat., Bot., sér. 5 , xv.

Dangeard, P. A. ('00): Recherches sur la structure du Polyphagus Euglenae, Now. Le Botaniste, sér. vii.

('06): Les ancêtres des Champignons supérieurs. Le Bot., sér. ix.

ERnst, A. ('02): Siphoneen-Studien, I. Beihefte zum Bot. Centralbl., xiii.

Fischer, A. ('92): Phycomycetes, in Rabenhorst's Kryptogamen. Flora, i, Abt. 4.

LAGER HeIM, G. ('00): Mykologische Studien. II : Untersuchungen über die Monoblepharideen. K. Svensk. Vet. Ak. Handl., xxv.

Lotsy, J. P. ('07) : Vorträge über botanische Stammesgeschichte, i.

Maurizio, A. ('96): Die Sporangiumanlage der Gattung Saprolegnia. Pringsh. Jahrb., xxix。

Petersen, H. E. ('10): An Account of Danish Freshwater Phycomycetes. Ann. Myc., viii. 
Pringsheim, N. ('85) : Ueber Cellulinkörner. Ber. d. deut. bot. Gesellsch., i. Reinsch, P. F. ('78): Beobachtungen über einige neue Saprolegnieae, \&c. Pringsh. Jahrb., xi. Rothert, W. ('90): Die Entwickelung der Sporangien bei den Saprolegnieen. Cohn's Beiträge, v. Schroeter, J. ('92) : Phycomycetes, in Engler und Prantl : Die natürl. Pflanzenfam., Teil I, Abt. i. Thaxter, R. ('95): Gonapodya and Myrioblepharis. Bot. Gaz., xx.

('96): Blastocladia. Bot. Gaz., xxi.

Vuillemin, P. ('07): Les bases actuelles de la systématique en Mycologie. Progressus Rei Bot., ii.

\title{
EXPLANATION OF FIGURES $1-18$.
}

\author{
Illustrating Dr. Butler's paper on Allomyces.
}

Fig. I. Single plant showing basal body, rhizoids, and fertile branches which bear sporangia and a few resting spores. At $a$ the lowest sporangium was formed after the upper was cut off and the axis had continued to grow from below it.

Fig. 2. Much branched basal body; branching dichotomous.

Fig. 3. Unbranched columnar basal body.

Fig. 4. Sub-dichotomously branched fertile hypha.

Fig. 5. Sympodial fertile hypha.

Fig. 6. Cluster of sporangia at the end of a fertile hypha.

Fig. 7. A chain of ripe sporangia with papillae formed, just before discharge.

Fig. 8. A chain of irregularly shaped sporangia.

Fig. 9. Sporangium discharging zoospores through three openings.

Fig. Io. Zoospores. At the top five zoospores just after emergence, showing the elongated shape, hyaline cap, and single posterior cilium; on the left amoeboid changes in shape of a single zoospore shortly after emergence, cilium not shown; at the bottom four zoospores in the final shape taken during the period of active swarming.

Fig. II. Zoospore germinating with a branched germ tube.

Fig. 12. Resting spore in surface view.

Fig. 13. Details of the wall of a resting spore which completely filled the terminal cell of the hypha. The outer thin wall is that of the hypha; next is the thick exospore with pits (?) seen in optical section as dark bands; inside the structureless endospore.

Fig. 14. Surface view of the wall of the exospore showing the pits (?).

Fig. I 5. Two resting spores formed free within the terminal cell of the hypha; that on the right is being set free by the rupture of the hyphal wall.

Fig. 16. Resting spore completely filling terminal cell, the wall of which cannot be made out except at the lower part of the spore. Optical section through middle of spore.

Fig. I 7. Details of septum formation. (a) Cellulin bodies collected at the origin of a lateral branch. (b) Same in surface view. (c) Peripheral interrupted plate in surface and profile view. (d) A septum of the basal body completed, with cellulin bodies grouped above and below. (e) Mature septa, upper unusually thickened, lower of the type ordinarily found in the fertile hyphae.

Fig. 18. Structure of protoplasm of a fertile hypha; lower portion reticulate, upper finely granular. 
Butler.-On Allomyces, a new Aquatic Fungus. I035

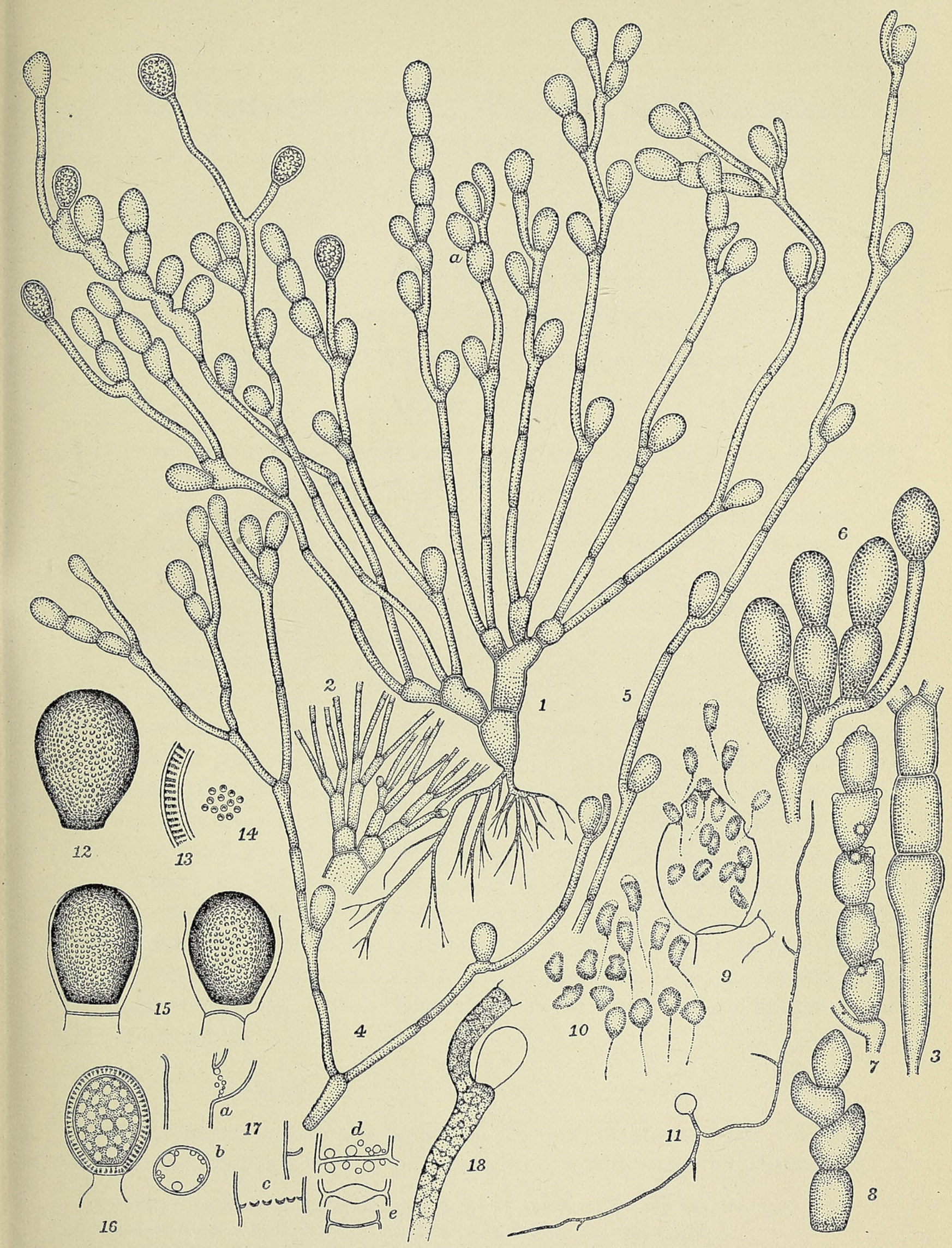




\section{$2 \mathrm{BHL}$ Biodiversity Heritage Library}

Butler, E.J. 1911. "On Allomyces, a new aquatic fungus." Annals of botany 25, 1023-1035. https://doi.org/10.1093/oxfordjournals.aob.a089359.

View This Item Online: https://www.biodiversitylibrary.org/item/239487

DOI: https://doi.org/10.1093/oxfordjournals.aob.a089359

Permalink: https://www.biodiversitylibrary.org/partpdf/319874

\section{Holding Institution}

Smithsonian Libraries

\section{Sponsored by}

Biodiversity Heritage Library

\section{Copyright \& Reuse}

Copyright Status: Not in copyright. The BHL knows of no copyright restrictions on this item.

This document was created from content at the Biodiversity Heritage Library, the world's largest open access digital library for biodiversity literature and archives. Visit BHL at https://www.biodiversitylibrary.org. 